\title{
E-Modul Strategi Pembelajaran Anak Usia Dini Sebagai Sumber Belajar Digital
}

\section{W. Sutama1*, W. Astuti2 ${ }^{2}$ N. Anisa $^{3}$}

1,2,3Jurusan Kependidikan Sekolah Dasar, Universitas Negeri Malang, Malang, Indonesia

\section{ART I CLE I N F O}

Article history:

Received October 20, 2021

Revised October 21, 2021

Accepted November 20, 2021

Available online December 25, 2021

Kata Kunci:

E-Modul, Sumber Belajar, Digital

Keywords:

E-Modul, Learning Resources, Digiital

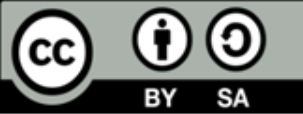

This is an open access article under the CC BY-SA license.

Copyright (C) 2021 by Author. Published by Universitas Pendidikan Ganesha.

\begin{abstract}
A B S T R A K
Era digital berdampak pada semua aspek kehidupan termasuk dalam pendidikan dan pembelajaran. Pembelajaran berubah dari pola tatap muka menuju ke arah dalam jaringan. Kemudahan dan mobilitas pembelajaran untuk mahasiswa S1 PGPAUD belum didukung oleh sumber belajar yang fleksibel, mudah diakses dan adaptif serta terprogram, sehingga mereka masih tergantung pada kehadiran dosen melalui web meeting dan atau tatap muka. Untuk memecahkan permasalahan tersebut, diperlukan sumber dan program pembelajaran yang efektif dan efisien, serta menarik sehingga mahasiswa dapat belajar secara mandiri maupun kolaboratif secara online. Tujuan penelitian ini adalah untuk mengembangkan e-modul strategi pembelajaran anak usia dini, yang efektif, efisien dan menarik. Metode yang digunakan adalah penelitian dan pengembangan model Borg \& Gall. Subyek penelitian ini adalah mahasiswa S1 PGPAUD sejumlah 15 orang untuk uji kelompok kecil dan 40 orang untuk uji kelompok besar. Selain itu melibatkan penguji ahli materi dan desain pembelajaran masing-masing 2 orang. Untuk penguji ahli materi berasal dari dosen S1 PGPAUD dan penguji ahli desain dari dosen jurusan Teknologi Pembelajaran. Metode pengumpulan data dilakukan melalui penyebaran quisener dalam bentuk google form. Analisis data menggunakan teknik prosentase. Simpulan penelitian ini adalah bahwa e-modul ini sangat layak digunakan sebagai salah satu sumber belajar digital pada matakuliah Strategi pembelajaran Anak Usia Dini, karena memenuhi unsur keefektivan, keefisienan, dan kemenarikan.
\end{abstract}

\section{A B S T R A C T}

The digital era has an impact on all aspects of life, including education and learning. Learning is changing from a face-to-face pattern to an online direction. The ease and mobility of learning for S1 PGPAUD students have not been supported by flexible, accessible and adaptive and programmed learning resources, so they still depend on the presence of lecturers through web meetings and or face-to-face. To solve these problems, effective and efficient, and interesting learning resources and programs are needed so that students can study independently and collaboratively online. The purpose of this study is to develop an e-module of early childhood learning strategies, which is effective, efficient and attractive. The method used is the research and development of the Borg \& Gall model. The subjects of this study were 15 students of S1 PGPAUD for the small group test and 40 people for the large group test. In addition, it involved 2 examiners of material and learning design experts each. The material expert examiners come from PGPAUD S1 lecturers and design expert examiners from lecturers in the Department of Learning Technology. The method of data collection is done through the distribution of questionnaires in the form of google form. Data analysis using percentage technique. The conclusion of this study is that this e-module is very suitable to be used as a digital learning resource in the Early Childhood Learning Strategy course, because it meets the elements of effectiveness, efficiency, and attractiveness.

\section{PENDAHULUAN}

Pola kehidupan akhir-akhir ini sangat dinamis dan segalanya cepat berubah. Hal ini disebabkan oleh perkembangan teknologi informasi yang mengarah pada era digitalisasi (Jonassen et al., 1999; Latip, 2020). Perkembangan tersebut berdampak pada perubahan aspek-aspek kehidupan, termasuk di dalamnya adalah bidang pendidikan. Dampak positif yang diakibatkan oleh teknologi adalah menjadikan pendidikan lebih efisien dalam masalah waktu, biaya, logistik dan masalah kelembagaan lainnya. Sedangkan dampak negatifnya adalah teknologi dapat merubah kehidupan sosial secara sangat cepat, sehingga pendidikan 
harus lebih dinamis dan adaptabel terhadap perkembangan teknologi dan masyarakat (Lestari, 2018), dan terjadinya perubahan perilaku, etika, norma, aturan, atau moral kehidupan yang bertentangan dengan etika, norma, aturan, dan moral kehidupan yang ada pada masyarakat (Jamun, 2018). Dinamika tersebut menjadi tantangan bagi lembaga pendidikan agar dalam pembelajaran menekankan pada pengalaman belajar yang mengarah pada kompetensi keterampilan berpikir kritis, inovatif dan kreatif, kolaboratif dan membangun networking serta berkomunikasi secara efektif (Arnyana, 2019; Prayogi \& Estetika, 2019). Oleh karena itu diperlukan literasi digital (literasi media dan tekhnologi informasi komunikasi), numerikal, bahasa, ekonomi, sosial, sosial, budaya dan informasi (Atika et al., 2019; Rachmatin \& Dewi, 2019). Hal ini diperlukan agar sumber daya manusia menjadi lebih adaptif dan produktif sehingga dapat menjaga eksistensinya ke depan. Kemampuan beradaptasi diperlukan sebagai antisipasi terhadap kondisi yang ditandai semakin bertautnya dunia ilmu pengetahuan, sehingga sinergi di antaranya menjadi semakin cepat. Produktivitas diperlukan agar manusia bukan hanya sebagai konsumen dari teknologi informasi, tetapi menjadi pencipta/kreator pada berbagai aspek kehidupan (ekonomi, sosial, budaya, pengetahuan, teknologi dan pendidikan). Kemudahan-kemudahan yang ditimbulkan oleh perkembangan tersebut, karena konteks pemanfaatan teknologi informasi dan komunikasi, telah terbukti semakin menyempitnya dan meleburnya faktor "ruang dan waktu" yang selama ini menjadi aspek penentu kecepatan dan keberhasilan penguasaan ilmu pengetahuan oleh umat manusia (Nyoto \& Amat, 2016).

Untuk menghadapi tantangan tersebut, maka diperlukan pengembangan sumberdaya manusia yang berkualitas, melalui penerapan strategi pembelajaran yang dapat memfasilitasi terpicunya higher order thinking skills mulai dari jenjang pendidikan anak usia dini sampai ke jenjang pendidikan tinggi (Antara et al., 2020; Riadi \& Retnawati, 2014). Dengan perkembangan ilmu pengetahuan dan teknologi informasi, maka pembelajaran menbjadi lebih fleksibel dan bersifat mobile. Pola pembelajaran mulai berubah dari tatap muka menjadi pembelajaran secara dalam jaringan (daring) (Daniati, 2020; Jayul \& Irwanto, 2020). Proses pembelajaran menjadi lebih fleksibel dan dapat dilakukan di mana saja, kapan saja dan bersumber dari mana saja. Sebagaimana dikemukakan oleh Clark N. Quinn bahwa mobile learning sebagai proses pembelajaran e-learning yang dilakukan oleh seseorang (pendidik atau peserta didik atau siapa saja) dapat terjadi setiap waktu, kapanpun mereka inginkan buat belajar sesuatu tema/topik yang ingin dipelajari dengan syarat haruslah terkoneksi dengan internet dan perangkat mobile pendukung yang mereka miliki (Efriyanti, 2020). Permasalahan yang dihadapi pada pembelajaran adalah kurangnya kebiasaan peserta didik/mahasiswa untuk mengakses berbagai sumber belajar yang bersifat online. Pendidik dan peserta didik pada satuan pendidikan memandang bahwa ketersediaan sumber belajar di satuan pendidikan tertentu masih sangat terbatas. Keterbatasan tersebut dirasakan pada beberapa aspek seperti aspek kualitas dan kuatitas sumber belajar, aspek variasi sumber belajar, aspek kemudahan akses terhadap sumber belajar, aspek bentuk dan jenis sumber belajar yang benar-benar tersedia (Supriadi, 2015; Susilowati, 2017). Selain itu untuk sumber belajar digital mengenai pendidikan anak usia dini juga masih terbatas. Hal ini menyebabkan mahasiswa dan peserta didik pada umumnya lebih mengandalkan pada sumber belajar tercetak, sementara perangkat teknologi informasi yang dimilikinya lebih banyak digunakan pada hal-hal yang non akademik. Jika dianalisis, faktor penyebabnya adalah karena sumber belajar digital belum memberikan pengalaman belajar yang menarik, dan hanya diakses pada saat mengerjakan tugas. Sebagian besar sumber belajar yang diakses terbatas pada webpage atau sumber informasi yang kadar ilmiahnya kurang.

Untuk mengatasi permasalahan tersebut, maka perlu dikembangkan sumber belajar digital yang efektif, efisien dan menarik, serta dapat diakses kapan saja, di mana saja dan dalam situasi apa saja. Tujuan penelitian ini adalah untuk menghasilkan e-Modul Strategi Pembelajaran Anak Usia Dini, yang efektif, efisien dan menarik, sehingga layak digunakan sebagai sumber belajar digital bagi mahasiswa PGPAUD. Sumber belajar digital yang dimaksud adalah berupa modul elektronik/digital (e-modul). E-Modul merupakan modifikasi dari modul konvensional dengan memadukan teknologi informasi, sehingga modul yang ada dapat lebih menarik dan interaktif. $e$-Modul dapat menambah fasilitas multimedia di dalamnya. Di dalam e-modul juga dapat ditambahkan fasilitas tes atau evaluasi interaktif sehingga siswa lebih dapat berinteraksi dengan sumber belajarnya (Kumalasani, 2020; Purwanto, 2017). Modul elektronik (e-Modul) merupakan pengembangan modul cetak dalam bentuk digital yang banyak mengadaptasi dari modul cetak (Rahmatika et al., 2020). Kelebihan e-modul dibandingkan dengan modul cetak adalah sifatnya yang interaktif memudahkan dalam navigasi, memungkinkan menampilkan/memuat gambar, audio, video, dan animasi serta dilengkapi tes/kuis formatif yang memungkinkan umpan balik otomatis dengan segera (Suarsana \& Mahayukti, 2013). Keunggulan lain e-modul dalam proses pembelajaran terletak pada tahapan pembelajaran berdasarkan masalah, yaitu orientasi peserta kuliah kepada masalah, mengorganisasi peserta kuliahuntuk belajar, membimbing penyelidikan individual maupun kelompok, mengembangkan dan menyajikan hasil karya, serta menganalisis dan mengevaluasi proses pemecahan masalah (Sugihartini \& Jayanta, 2017). Hasil penelitian menunjukkan bahwa 
Pengembangan e-modul memberikan beberapa keuntungan, di antaranya adalah sebagai berikut. (1) Penggunaan e-modul berorientasi pemecahan masalah, keterampilan berpikir kritis mahasiswa mengalami peningkatan dari 27,6 (sedang) menjadi 31,4 (tinggi). (2) Tanggapan mahasiswa terhadap pelaksanaan perkuliahan menggunakan $e$-modul berorientasi pemecahan masalah adalah sangat positif (Suarsana, 2013).

Pengembangan e-modul menjadi urgen karena untuk mengantisipasi dan beradaptasin dengan era digitalisasi yang memiliki dampak yang sangat signifikan dalam bidang pendidikan. Berbagai perubahan terjadi sangat cepat dan signifikan, baik dalam bidang pengambilan kebijakan maupun dalam praktik pendidikan di kelas. Guru bukan lagi menjadi penentu tunggal dalam pembelajaran, karena peserta didik dapat dengan mudah mencari dan mengeksplorasi berbagai sumber belajar digital yang jauh lebih cepat dan praktis. Oleh karena itu pendidikan hasus bersifat adaptif dan antisipatif terhadap kecenderungan perubahan peradaban di era digital sekarang ini. Terlebih lagi pada abad 21 ini, lulusan lembaga pendidikan harus bersaing dengan produk dan penerapan artificial intelligence (kecerdasan buatan) (Rodrigues, 2020). Untuk mengantisipasi dan beradaptasi terhadap fenomena ini, Pengembangan dan pemanfaatan e-modul dalam pembelajaran mnerupaka implementasi dari model pembelajaran berbasis TPACK (Technological Pedagogical Content Knowledge) (Feladi et al., 2020; Koh et al., 2015). Rancangan e-modul memungkinkan guru menyiapkan peserta didik belajar mandiri dan berkolaborasi dalam memecahkan masalah secara kompleks, mereka dapat dilatih untuk melakukan identifikasi masalah yang terjadi di sekelilingnya. Langkah selanjutnya adalah menentukan inti masalah, menganalisis berbagai faktor penyebab, menentukan penyebab utama dari permasalahan tersebut. Setelah menemukan faktor penyebab utama, selanjutnya mereka diarahkan untuk menentukan alternatif penyelesaian masalah serta melakukan aksi/tindakan untuk menyelesaikan masalah, berbasis teknologi sehingga dominasi guru dalam melakukan intervensi belajar seminimal mungkin. Hasil penelitian menunjukkan bahwa bahwa terdapat perbedaan kemampuan berpikir kritis dan kemampuan berpikir kreatif secara bersama-sama antara kelompok mahasiswa yang belajar dengan model pembelajaran berbasis masalah dan model pembelajaran ekspositori (Rosa \& Pujiati, 2016).

Berpikir kritis merupakan kemampuan dalam menganalisis dan mengevaluasi informasi yang didapat dari hasil pengamatan, pengalaman, penalaran maupun komunikasi untuk memutuskan apakah informasi tersebut dapat dipercaya sehingga dapat memberikan kesimpulan yang rasional dan benar (Nugraha et al., 2017; Purwati et al., 2016). Berpikir kritis mengarah pada kemampuan berpikir rasional, dan membentuk strategi yang akan meningkatkan kemungkinan hasil yang diharapkan atau proses kognitif yang memilikin tujuan yang jelas, beralasan, dan berorientasi pada sasaran (Kumullah et al., 2018; Wahyuningtyas \& Shinta, 2017). Salah satu kompetensi abad 21 adalah kreativitas dan inovasi. Kreativitas penting untuk dioptimalkan karena dalam kehidupan sehari-hari peserta didik dihadapkan dengan berbagai persoalan, sehingga mereka dapat memecahkan suatu permasalahan serta berpengaruh kepada prestasi akademiknya (Sari et al., 2020). Kreativitas menekan pada kemampuan untuk menghasilkan sesuatu secara original sebagai bentuk untuk memecahkan masalah yang ada secara inovatif. Hal lain yang juga memiliki peran yang sangat penting di era digital ini adalah kemampuan untuk mengatur, memimpin dan memanfaatkan sumber daya manusia secara tepat sasaran dan efektif. Pemimpin yang cerdas adalah mereka yang dapat memaksimalkan jam kerja dengan belajar untuk mendelegasikan, memprioritaskan dan juga berusaha untuk menyederhanakan masalah. Kepemimpinan (leadership) berkenaan dengan seseorang memengaruhi perilaku orang lain untuk suatu tujuan. Aktivitas manajemen, mencakup perencanaan, pengarahan, pengorganisasian, dan pengendalian (Yudiaatmaja, 2013). Membangun jejaring (networking) menjadi sebuah kebutuhan yang krusial dalam era digital ini. Dengan perkembangan teknologi informasi, manusia dapat berhubungan secara global. Kemudahan ini perlu dimanfaatkan untuk membangun kerjasama tim ataupun bekerja dengan orang lain yang berasal dari luar tim, serta membangun jaringan kerja yang luas bahkan lintas negara. Hal ini bertujuan agar dalam menangani suatu masalah bukan hanya agar masalah tersebut cepat tuntas, namun berkolaborasi dalam tim juga membuat suatu korporasi menjadi lebih tangguh dan kesuksesan mudah tergapai. Selain itu membangun jejaring kerja merupakan sebuah proses membangun komunikasi atau hubungan, berbagi ide, informasi dan sumber daya atas dasar saling percaya dan saling menguntungkan di antara pihak-pihak yang berkolaborasi/bermitra untuk mencapai kesuksesan bersama yang lebih besar (Sutrisno, 2017).

E-modul memberikan bentuk penyajian bahan belajar mandiri yang disusun secara sistematis ke dalam unit pembelajaran terkecil untuk mencapai tujuan pembelajaran tertentu yang disajikan ke dalam format elektronik yang di dalamnya terdapat animasi, audio, navigasi yang membuat pengguna lebih interaktif dengan program. E-modul bersifat interaktif dan menarik karena melibatkan tampilan audio visual, sound, movie dan yang lainnya serta program tersebut pemakaiannya mudah dipahami (Sugianto, 2013). Selain itu juga bersifat praktis, bisa dipelajari di mana saja, kapan saja dan menggunakan aplikasi yang sangat sederhana. E-Modul ini mampu memberikan pengalaman belajar yang bersifat blended, karena 
mampu memberikan contoh-contoh dalam format audio-visual. Pengembangan e-modul diperlukan untuk memfasilitasi mahasiswa program S1 PGPAUD dalam mengikuti perkuliahan Strategi Pembelajaran Anak Usia Dini, sehingga mereka dapat mempelajari substansi kajian strategi pembelajaran baik makro maupun mikro secara mandiri dan kolaboratif mengingat kondisi saat ini belum dimungkinkan terjadinya perkuliahan tatap muka. Selain itu, ke depan dengan konsep kampus merdeka dan merdeka belajar, keperluan untuk bahan ajar bersifat digital sangat urgen sehingga akses perkuliahan menjadi semakin dinamis, efektif dan efisien, dengan memanfaatkan teknologi. Dengan demikian, ruang gerak perkuliahan semakin luas dan mengglobal.

Tujuan khusus pengembangan e-modul ini adalah untuk menghasilkan modul berbasis digital, yang dengan mudah dapat diakses oleh mahasiswa sehingga mereka dapat belajar secara mandiri dan kolaboratif berbasis digital. Hal ini menjadi suatu kebutuhan mutlak karena di era digital penggunaan teknologi menjadi hal yang sangat penting dalam menyiapkan sumber daya manusia yang berkualitas. Penggunaan E-learning di dunia pendidikan adalah bentuk pengembangan dari Teknologi Informasi pendidikan, dimana Teknologi Informasi memiliki beberapa tujuan dan pemanfaatan yaitu (1) memperbaiki competitive positioning; (2) meningkatkan brand image; (3) meningkatkan kualitas pembelajaran dan pengajaran; (4) meningkatkan kepuasan mahasiswa; (5) meningkatkan pendapatan; (6) memperluas basis mahasiswa; (7) meningkatkan kualitas pelayanan; (8) mengurangi biaya operasi; dan (9) mengembangkan produk dan layanan baru (Afrizawati \& Yusuf, 2016). Melalui emodul, mahasiswa memperoleh pengalaman belajar yang utuh, karena dikemas secara blanded learning dengan mengkombinasikan multi sumber, multi metode, multi media dan pemanfaatan teknologi informasi secara maksimal. Hal ini akan dapat memicu kemampuan berpikir kritis dan evaluatif, kreativitas, inovasi dan produktivitas melalui proses belajar yang bersifat kolaboratif (dalam pembelajaran daring dapat menggunakan google docs) dan terbiasa mempublikasikan ide, gagasan dan produknya sehingga mahasiswa dapat memperbaiki competitive positioning; brand image dan meningkatkan pendapatannya.

\section{METODE}

Penelitian dan pengembangan ini bertujuan untuk menghasilkan e-modul untuk matakuliah Strategi Pembelajaran Anak Usia Dini jenjang S1. Proses pengembangan menggunakan model alur Borg dan Gall (Borg \& Gall, 2007). Adapun langkah-langkah pengembangan Borg and Gall terdiri atas: (1) Research and information collecting, peneliti melakukan analisis kebutuhan dengan melakukan identifikasi struktur kurikulum, RPS dan SAP serta kelengkapan dokumen pembelajaran dalam SIPEJAR UM. (2) Planning: menyusun RPS, SAP matakuliah Strategi Pembelajaran Anak Usia Dini. (3) Develop preliminary form of product: menyusun draft e-modul dalam bentuk fileword, kemudian save as ke dalam bentuk pdf, selanjutnya diolah dengan aplikasi Kvisoft flip book maker. (4) Preliminary field testing: melakukan expert judgement dengan melibatkan ahli teknologi pembelajaran, ahli materi bidang ke-PAUD-an masing-masing minimal 2 orang ahli. (5) Main product revision: melakukan revisi terhadap prototipe e-modul berdasarkan masukan dari ahli pada saat expert juggement. (6) Main field testing: melakukan uji coba kelompok kecil melalui sampel dari 3 kelas mahasiswa secara proporsional random sampling. (7) Operational product revision: melakukan revisi berdasarkan hasil uji coba kelompok kecil. (8) Operational field testing: melakukan uji coba kelompok besar yakni pada mahasiswa prodi PGPAUD FIP UM. (9) Final product revision: melakukan revisi akhir terhadap e-modul berdasarkan hasil uji coba kelompok besar. (10) Dissemination and implementation: melakukan deseminasi dan menerapkannya dalam perkuliahan Strategi Pembelajaran AUD. Khusus untuk langkah ke 10 tidak dilakukan karena perkuliahan strategi pembelajaran berlangsung pada semester genap.

Uji ahli dibidang desain dilakukan oleh 2 orang dosen dari jurusan Teknologi Pembelajaran FIP Universitas Negeri Malang. Uji ahli materi pendidikan anak usia dini dilakukan oleh dosen program studi Pendidikan Guru Pendidikan Anak Usia Dini. Uji kelompok terbatas dilakukan pada mahasiswa angkatan tahun 2019 sejumlah 15 orang dan uji kelompok besar sejumlah 40 orang. Metode pengumpulan data dilakukan melalui penyebaran instrumen penilaian melalui google form. Unsur yang dinilai pada aspek desain meliputi aspek keefektivan, keefisienan dan kemenarikan. Unsur yang dinilai oleh ahli materi meliputi aspek kesesuaian isi dengan dengan karakteristik mahasiswa PGPAUD, dengan silabus perkuliahan, dapat meningkatkan kemampuan mahasiswa PGPAUD dalam memberikan stimulasi HOTS untuk AUD, dapat menarik mahasiswa PGPAUD untuk memberikan stimulasi HOTS kepada AUD, dan telah tepat disusun dari materi yang paling dasar hingga kepada implementasinya. Untuk validasi kelompok kecil dan besar aspek yang dinilai meliputi aspek keefektifan, keefisienan penggunaan dan tingkat kemenarikan isi dan desain e-modul. 


\section{HASIL DAN PEMBAHASAN}

Hasil

Berdasarkan hasil uji validasi terhadap e-modul Strategi Pembelajaran untuk Anak Usia Dini, diperoleh data sebagai berikut. Hasil uji ahli desain menunjukkan bahwa e-modul ini sangat layak dengan capaian skor 96,88\%. Adapun hasil uji ahli desain disajikan pada Tabel 1.

Tabel 1. Hasil Uji Ahli Desain

\begin{tabular}{|c|c|c|c|c|}
\hline \multirow[t]{2}{*}{ No } & \multirow{2}{*}{ No. item pertanyaan } & \multicolumn{2}{|c|}{ skor } & \multirow{2}{*}{ Skor total } \\
\hline & & Validator 1 & Validator 2 & \\
\hline 1 & 1 & 4 & 4 & 8 \\
\hline 2 & 2 & 4 & 4 & 8 \\
\hline 3 & 3 & 3 & 4 & 7 \\
\hline 4 & 4 & 4 & 4 & 8 \\
\hline 5 & 5 & 3 & 4 & 7 \\
\hline 6 & 6 & 4 & 4 & 8 \\
\hline 7 & 7 & 4 & 4 & 8 \\
\hline 8 & 8 & 4 & 4 & 8 \\
\hline \multicolumn{4}{|c|}{ Skor Total } & 62 \\
\hline \multicolumn{4}{|c|}{ Persentase } & 96,88 \\
\hline
\end{tabular}

Catatan yang diberikan oleh penguji ahli desain adalah sebagai berikut. (a) Desain Layout yang sederhana dan menarik, tidak terlalu banyak ornamen atau fitur yang tidak perlu dalam lembar-lembar halaman. (b) Menarik, hanya perlu diperiksa kembali konsistensi penataan elemen-elemen pada halaman pembuka BAB, sumber gambar dan nomor halaman. (c) Secara substansial E-Modul sudah layak sebagai sumber belajar digital untuk membekali mahasiswa keterampilan Abad 21 dan mempersiapkan mereka untuk membelajarkan siswa PAUD keterampilan Abad 21. Secara desain perlu diperiksa kembali elemenelemen dalam tiap halamannya terkait konsistensi elemen-nya. (d) Perlu optimalisasi pada aspek estetika visual. Hasil uji ahli materi pada Tabel 2 menunjukkan bahwa e-modul Strategi Pembelajaran untuk Anak Usia dini ini diperoleh skor persentase 92.5. Hal ini menunjukkan bahwa materi e-modul Strategi Pembelajaran untuk Anak Usia Dini sangat sesuai dengan karakteristik mahasiswa PGPAUD, sesuai dengan silabus perkuliahan di PGPAUD, dapat meningkatkan kemampuan mahasiswa PGPAUD dalam memberikan stimulasi HOTS untuk AUD, dapat memfasilitasi mahasiswa PGPAUD untuk memberikan stimulasi HOTS kepada AUD, dan telah disusun dengan tepat dari materi yang paling dasar hingga kepada implementasinya.

Tabel 2. Hasil Uji Ahli Materi

\begin{tabular}{ccccc}
\hline No & No. item pertanyaan & \multicolumn{2}{c}{ skor } & \multirow{2}{*}{ Skor total } \\
\cline { 3 - 4 } & & Validator 1 & Validator 2 & \\
\hline $\mathbf{1}$ & 1 & 4 & 3 & 7 \\
$\mathbf{2}$ & 2 & 4 & 4 & 8 \\
$\mathbf{3}$ & 3 & 4 & 3 & 7 \\
$\mathbf{4}$ & 4 & 4 & 4 & 8 \\
$\mathbf{5}$ & 5 & 3 & 7 \\
\hline \multicolumn{3}{c}{ Skor total } \\
\hline
\end{tabular}

Catatan yang diberikan oleh ahli materi meliputi: (a) Kualitas isi: baik perlu diperhatikan konsitensi penggunaan kata. Misal; yang digunakan kata "Anda"/"Saudara"/"Mahasiswa". (b) Pperlu dicek kembali link yang disematkan untuk bisa diakses oleh pengguna e-modul (ada yang tidak dapat diakses salahsatunya pada hal. 8 e-modul 2). (c) untuk website "sekolah" yang dijadikan contoh sebaiknya tambahkan yang dari Indonesia (mungkin sedikit sulit mendapatkan website yang sesuai tujuan). (c) Alangkah lebih baik dilengkapi dengan video pembelajaran berbasis HOTs sebagai contoh implementasinya secara audio visual.

Hasil uji coba kelompok kecil diperoleh persentase sebanyak 86.85. Hal ini menunjukkan bahwa emodul Strategi Pembelajaran untuk Anak Usia Dini sangat layak untuk digunakan, walaupun masih ada beberapa catatan dari pengguna. Catatan tersebut adalah (a) masih sulit untuk dilirik pengguna karena ketidaktahuan untuk mengaksesnya atau mungkin kurang praktis. Karena kurangnya informasi penggunaannya. (b) cover atau sampul dari modul pembelajaran mungkin dapat diberikan latar belakang berupa gambar atau animasi-animasi yang menarik perhatian pembaca. (c) Sebaiknya menggunakan file 
pdf atau memasukkan file ke dalam gdrive kemudian dikirim kepada mahasiswa. Karena jika dikirim melalui format rar, tidak semua hp mendukung format tersebut.

Setelah dilakukan perbaikan berdasarkan berbagai masukan dari ahli desain, materi dan hasil uji kelompok kecil, maka dilakukan perbaikan, baik dari unsur desain dan isinya. Selanjutnya dilakukan uji kelompok besar. Hasil uji kelompok besar diperoleh skor sebesar 0.8986 atau 89,86\%. Hal ini berarti emodul Strategi Pembelajaran untuk Anak Usia dini ini sangat layak digunakan sebagai salah satu sumber belajar digital bagi mahasiswa S1 PGPAUD. Walaupun demikian, masih ada masukan dari mahasiswa, yaitu sebagai berikut. (a) alam mengakses e-modul agak sulit. Mungkin akses dapat dipermudah dengan cara dijadikan pdf atau semacamnya. (b) sebaiknya bisa digunakan melalui perangkat lunak aplikasi yg dapat dikembangkan seiring dengan kemajuan dan perkembangan teknologi 5.0 dengan kecanggihan tekhnologi yang berkembang bisa juga dioperasikan secara luas pada smartphone, tidak terbatas pada Personal Computer (PC).

\section{Pembahasan}

Berdasarkan hasil uji desain, materi dan pengguna dapat disimpulkan bahwa e-modul strategi pembelajaran untuk anak usia dini dapat dijadikan dan sangat layak untuk menjadi salah satu sumber belajar digital. Kelebihan sumber belajar digital antara lain 1) membangkitkan motivasi kepada peserta didik dalam belajar, 2) warna, musik, dan grafis animasi dapat menambahkan kesan realisme, 3) menghasilkan penguatan yang tinggi (Sudatha et al., 2020). Hasil penelitian juga menunjukkan bahwa ada pengaruh yang positif dan signifikan secara bersama-sama persepsi guru tentang digital nativesdan persepsi guru tentang sumber belajar digital terhadap motivasi guru memanfaatkan sumber belajar digital (Dopo \& Ismaniat, 2017). Pendapat pengguna (dalam hal ini mahasiswa) bahwa e-modul yang dikembangkan sangat efektif, efisien dan menarik. Hal ini sesuai dengan pendapat (Partono, 2019) yang mengemukakan bahwa kelebihan e-Modul dibandingkan dengan modul konvensional adalah (a) lebih menarik, karena dapat dilengkapi dengan fasilitas multimedia (gambar, animasi, audio dan video). (b) Lebih interkatif karena siswa dapat melakukan evaluasi diri terhadap suatu kompetensi sekaligus dapat melakukan tindak lanjut setelah mengetahui hasil evaluasi yang dilakukannya secara mandiri. (c) Paperless, dengan demikian penggunaan kertas dapat diminimalkan. (d) Multiplatform, e-Modul dapat digunakan pada berbagai peralatan (device) baik komputer dekstop, laptop maupun smartphone.

E-modul memberikan bentuk penyajian bahan belajar mandiri yang disusun secara sistematis ke dalam unit pembelajaran terkecil untuk mencapai tujuan pembelajaran tertentu yang disajikan ke dalam format elektronik yang di dalamnya terdapat animasi, audio, navigasi yang membuat pengguna lebih interaktif dengan program. E-modul bersifat interaktif dan menarik karena melibatkan tampilan audio visual, sound, movie dan yang lainnya serta program tersebut pemakaiannya mudah dipahami (Sugianto, 2013). Selain itu juga bersifat praktis, bisa dipelajari di mana saja, kapan saja dan menggunakan aplikasi yang sangat sederhana. E-Modul ini mampu memberikan pengalaman belajar yang bersifat blended, karena mampu memberikan contoh-contoh dalam format audio-visual. Pengembangan e-modul diperlukan untuk memfasilitasi mahasiswa program S1 PGPAUD dalam mengikuti perkuliahan Strategi Pembelajaran Anak Usia Dini, sehingga mereka dapat mempelajari substansi kajian strategi pembelajaran baik makro maupun mikro secara mandiri dan kolaboratif mengingat kondisi saat ini belum dimungkinkan terjadinya perkuliahan tatap muka. Selain itu, ke depan dengan konsep kampus merdeka dan merdeka belajar, keperluan untuk bahan ajar bersifat digital sangat urgen sehingga akses perkuliahan menjadi semakin dinamis, efektif dan efisien, dengan memanfaatkan teknologi. Dengan demikian, ruang gerak perkuliahan semakin luas dan mengglobal.

Dengan demikian pengembangan e-modul Strategi pembelajaran untuk Anak Usia dini sudah memenuhi unsur keefektivan, keefisienan dan kemenarikan, sehingga layak digunakan sebagai sumber belajar digital. Selain itu, pemanfaatan e-modul dalam pembelajaran lebih fleksibel, dinamis dan dapaat digunakan secara mobile, sehingga dapat digunakan di mana saja, kapan saja tanpa tersekat oleh ruang dan waktu. Mahasiswa dan pembaca linnya juga dapat dengan mudah mengakses dengan berbagai perangkat berbasis IT, sehingga hal ini memiliki daya tarik tersendiri bagi penggunanya. Kontribusi dari penelitian dan pengembangan e-modul Strategi pembelajaran ini adalah dapat memberikan alternatif sumber belajar digital, yang murah, efektif dan efisien bagi mahasiswa program studi PGPAUD khususnya dan bagi praktisi pendidikan anak usia dini, terutama guru PAUD dan pengambil kebijakan di bidang pembelajaran anak usia dini. Keterbatasan penelitian ini terletak pada kuantitas penguji ahli, yaitu hanya dari satu universitas saja, dan sasaran uji coba kelompok kecil dan kelompok besar hanya berasal dari satu perguruan tinggi saja. Bagi peneliti selanjutnya diharapkan dapat memperluas sasaran uji coba dan menerapkannya langsung pada sasaran yang lebih luas yaitu lintas perguruan tinggi. 


\section{SIMPULAN}

Berdasarkan hasil uji ahli dan pengguna, dapat disimpulkan bahwa e-modul Strategi Pembelajaran untuk Anak Usia Dini tergolong sangat layak untuk digunakan sebagai sumber belajar digital pada perkuliahan Strategi pembelajaran Anak Usia Dini. Hal ini karena sudah memenuhi kriteria keefektivan, keefisienan, kemenarikan dan kesesuaian isi dengan silabus matakuliah Strategi Pembelajaran Anak Usia Dini. Selain itu pengguna juga memberikan respon positif bahwa dengan adanya sumber belajar digital berupa e-modul dapat mempelajarinya secara lebih dinamis dengan menggunakan berbagai perangkat berbasis IT, serta memperoleh pengalaman belajar yang praktis karena isinya sesuai dengan perkembangan jaman dan kompetensi abad 21 yang menuntut peserta didik untuk memiliki keterampilan berpikir kritis, dan memecahkan masalah, kreatif dan inovatif, kolaboratif dan komunikatif.

\section{DAFTAR RUJUKAN}

Afrizawati, P., \& Yusuf, M. (2016). Pengaruh E-Learning Dalam Pengembangan Teknoogi Informasi Pendidikan Di Politeknik Negeri Sriwijaya (Rekayasa Dan Non Rekayasa). Jurnal Manajemen Dan Bisnis Sriwijaya, 14(4). https://core.ac.uk/download/pdf/267823833.pdf.

Antara, I. G. W. S., Sudarma, I. K., \& Dibia, I. K. (2020). The Assessment Instrument of Mathematics Learning Outcomes Based on HOTS Toward Two-Dimensional Geometry Topic. Indonesian Journal of Educational Research and Review, 3(2), 19-24. https://doi.org/ijerr.v3i2.25869.g15588.

Arnyana, I. B. P. (2019). Pembelajaran untuk Meningkatkan Kompetensi 4C (Communication, Collaboration, Critical Thinking dan Creative Thinking) untuk Menyongsong Era Abad 21. Prosiding: Konferensi Nasional Matematika Dan IPA Universitas PGRI Banyuwangi, 1-13. https://ejournal.unibabwi.ac.id/index.php/knmipa/article/view/829.

Atika, I., Fatimah Zahro, Rissa, A., Munggaraning, S., \& Westhisi. (2019). Strategi Pembelajaran Literasi Sains Untuk Anak Usia Din. POTENSIA, 4(2), 123-130. https://ejournal.unib.ac.id/index.php/potensia/article/view/8241.

Borg, W., \& Gall, J. P. (2007). Educational research: An introduction. Pearson Education Inc.

Daniati, N. T. (2020). Video Referensi Sebagai Solusi Pembelajaran Animasi 3D di Tengah Pandemi Covid19. Ideguru: Jurnal Karya Ilmiah Guru. https://doi.org/10.51169/ideguru.v5i1.128.

Dopo, F. B., \& Ismaniat, C. (2017). Persepsi Guru Tentang Digital Natives , Sumber Belajar Digital Dan Motivasi Memanfaatkan Sumber Belajar Digital. Jurnal Inovasi Teknologi Pendidika, 3(1), 15-24. https://journal.uny.ac.id/index.php/jitp/article/view/8280.

Efriyanti, L. \& F. A. (2020). Aplikasi Mobile Learning Sebagai Sarana Pembelajaran Abad 21 bagi Pendidik dan Peserta Didik di era Revolusi Industri 4.0. Jurnal Educative : Journal of Educational Studies, 5(1). http://dx.doi.org/10.30983/educative.v5i1.3132.

Feladi, V., Hendriyani, Y., Dewi, I. P., Darni, R., \& Verawardina, U. (2020). The Profile of Technological Pedagogical and Content Knowledge of Information and Communication Technology Teachers. Test Engineering \& Management, 83, 1666-1673..

Jamun, Y. M. (2018). Dampak Teknologi Terhadap Pendidikan. Jurnal Pendidikan Dan Kebudayaan Missio, 10(1), 48-52. http://jurnal.unikastpaulus.ac.id/index.php/jpkm/article/view/54.

Jayul, A., \& Irwanto, E. (2020). Model Pembelajaran Daring Sebagai Alternatif Proses Kegiatan Belajar Pendidikan Jasmani di Tengah Pandemi Covid-19 Achmad. Jurnal Pendidikan Kesehatan Rekreasi, 6(2), 190-199. https://ojs.mahadewa.ac.id/index.php/jpkr/article/view/689.

Jonassen, D. H., Peck, K. L., \& Wilson, B. G. (1999). Learning with technology: A constructivist perspective. Special Education..

Koh, J. H. L., Chai, C. S., Benjamin, W., \& Hong, H. Y. (2015). Technological Pedagogical Content Knowledge (TPACK) and Design Thinking: A Framework to Support ICT Lesson Design for 21st Century Learning. Asia-Pacific Education Researcher, 24(3), 535-543. https://doi.org/10.1007/s40299015-0237-2.

Kumalasani, K. \& M. P. (2020). Digital Skillguru Melalui E-Modul Sebagai Inovasi Bahan Ajar Di Era Disrupsi 4.0. Jurnal Pendidikan Dasar, 1(1). https://doi.org/10.37729/jpd.

Kumullah, R., Djatmika, E. T., \& Lia, Y. (2018). Kemampuan berpikir kritis dan penguasaan konsep siswa dengan problem based learning pada materi sifat cahaya". Teori, Pnelitian Dan Pengembangan, 3(2014), 1583-1586. http://journal.um.ac.id/index.php/jptpp/article/view/11798.

Latip, A. (2020). Peran Literasi Teknologi Informasi dan Komunikasi Pada Pembelajaran Jarak Jauh di Masa Pandemi Covid-19. EduTeach: Jurnal Edukasi Dan Teknologi Pembelajaran, 1(2), 108-116. https://doi.org/10.37859/eduteach.v1i2.1956.

Lestari, S. (2018). Peran Teknologi Dalam Pendidikan Di Era Globalisasi. Edureligia, 2(2), 94-100. https://www.ejournal.unuja.ac.id/index.php/edureligia/article/view/459. 
Nugraha, A. J., Suyitno, H., \& Susilaningsih, E. (2017). Analisis Kemampuan Berpikir Kritis Ditinjau dari Keterampilan Proses Sains dan Motivasi Belajar melalui Model PBL. Journal of Primary Education, 6(1), 35-43. https://doi.org/10.15294/jpe.v6i1.14511.

Nyoto, E. Y. W., \& Amat, D. A. S. (2016). Transformasi Pendidikan Abad 21 sebagai Tuntutan Pengembangan Sumber Daya Manusia Di Era Global. Prosiding Seminar Nasional Pendidikan Matematika, 263-278.

Partono. (2019). Pemanfaatan Emodul Dalam Pembelajaran. SMAN 1 PEGANDON.

Prayogi, R. D., \& Estetika, R. (2019). Kecakapan Abad 21: Kompetensi Digital Pendidik Masa Depan. Manajemen Pendidikan, 14(2). http://journals.ums.ac.id/index.php/jmp/article/view/9486.

Purwanto, M. N. (2017). Psikologi Pendidikan. Remaja Rosda Karya.

Purwati, R., Hobri, H., \& Fatahillah, A. (2016). Analisis Kemampuan Berpikir Kritis Siswa dalam Menyelesaikan Masalah Persamaan Kuadrat Pada Pembelajaranmodel Creative Problem Solving. KadikmA, 7(1), 84-93. https://doi.org/10.19184/kdma.v7i1.5471.

Rachmatin, \& Dewi, A. S. (2019). Literasi Digital Abad 21 Bagi Mahasiswa PGSD: Apa, Mengapa, Dan Bagaimana? Current Research in Education: Conference Series Journal, 1(1), 1-7. https: //ejournal.upi.edu/index.php/crecs/article/view/14284.

Rahmatika, H., Lestari, S. R., \& Sari, M. S. (2020). A PBL-Based Circulatory System E-Module Based on Research Results to Improve Students 'Critical Thinking Skills and Cognitive Learning Outcome. 9(4), 565-575. https://doi.org/10.23887/jpi-undiksha.v9i4.25647.

Riadi, A., \& Retnawati, H. (2014). Pengembangan Perangkat Pembelajaran untuk Meningkatkan HOTS pada Kompetensi Bangun Ruang Sisi Datar Developing Learning Kit to Improve HOTS for Flat Side of Space Competence. Jurnal Pendidikan Matematika, 9(2), 126-135. http://journal.uny.ac.id/index.php/pythagoras.

Rodrigues, R. (2020). Legal and human rights issues of AI: gaps, challenges and vulnerabilities. Journal of Responsible Technology, 100005. https://doi.org/10.1016/j.jrt.2020.100005.

Rosa, N. M., \& Pujiati, A. (2016). Pengaruh Model Pembelajaran Berbasis Masalah Terhadap Kemampuan Berpikir Kritis Dan Kemampuan Berpikir Kreatif. Formatif: Jurnal Ilmiah Pendidikan MIPA, 6(3), 175-183,. https://journal.lppmunindra.ac.id/index.php/Formatif/article/view/990.

Sari, K. P., Neviyarni, \& Irdamurni. (2020). Pengembangan Kreativitas Dan Konsep Diri Anak SD. Pendidikan Dasar, $\quad 7(1)$ http://lppmunissula.com/jurnal.unissula.ac.id/index.php/pendas/article/view/7371.

Suarsana, I. M., \& Mahayukti, G. A. (2013). Pengembangan E-Modul Berorientasi Pemecahan Masalah Untuk Meningkatkan Keterampilan Berpikir Kritis Mahasiswa. Jurnal Pendidikan Indonesia, 2(2), 264275. http://dx.doi.org/10.23887/jpi-undiksha.v2i2.2171.

Sudatha, I. G. W., Parmiti, D. P., \& Simamora, A. H. (2020). Pengelolaan Sumber Belajar Digital Untuk Meningkatkan Pembelajaran Daring. Proceeding Senadimas Undiksha 2020, 1585-1589. https://lppm.undiksha.ac.id/senadimas2020/assets/ProsidingSenadimas2020/file/217.pdf.

Sugianto, D. (2013). Modul Virtual: Multimedia Flipbook Dasar Teknik Digital. Invotec, 9(2), 101-116. https://ejournal.upi.edu/index.php/invotec/article/view/4860.

Sugihartini, N., \& Jayanta, N. L. (2017). Pengembangan E-Modul Mata Kuliah Strategi Pembelajaran. Jurnal $\begin{array}{lllll}\text { Pendidikan Teknologi } & \text { Dan } & \end{array}$ https: //ejournal.undiksha.ac.id/index.php/JPTK/article/view/11830.

Supriadi. (2015). Pemanfaatan Sumber Belajar Dalam Proses Pembelajaran. Lantanida Journal, 3(127-139). https://www.jurnal.ar-raniry.ac.id/index.php/lantanida/article/view/1654.

Susilowati, S. (2017). Pengembangan Bahan Ajar IPA Terintegrasi Nilai Islam untuk Meningkatkan Sikap dan Prestasi Belajar IPA Siswa. Jurnal Inovasi Pendidikan IPA, 3(1), 78-88. https://doi.org/10.21831/jipi.v3i1.13677.

Sutrisno. (2017). Membangun Jejaring Kerja Sebagai Bagian Peningkatan Diklat. FORUM MANAJEMEN, 7(1), 1-15. http://ejurnal.ppsdmmigas.esdm.go.id/sp/index.php/swarapatra/article/view/162.

Wahyuningtyas, D. T., \& Shinta, R. N. (2017). Penggunaan Modul Pembelajaran Penjumlahan Dan Pengurangan Bilangan Bulat Dengan Pendekatan CTL (Contextual Teaching And Learning) Untuk Meningkatkan Pemahaman Konsep Siswa Kelas IV Sekolah Dasar. Jurnal Pendidikan (Teori Dan Praktik), 2(1), 12. https://doi.org/10.26740/jp.v2n1.p12-20.

Yudiaatmaja, F. (2013). Kepemimpinan: Konsep, Teori Dan Karakternya. Media Komunikasi FIS, 12(2), 2938. https://ejournal.undiksha.ac.id/index.php/mkfis/article/view/1681. 